\title{
Sub-clinical mastitis prevalent in dairy cows in Chittagong district of Bangladesh: detection by different screening tests
}

\author{
Mukti Barua ${ }^{1}$, Mohammad Abdul Matin Prodhan ${ }^{2}$, Kamrul Islam $^{3}$, Sharmin Chowdhury ${ }^{4}$, Md. Hasanuzzaman ${ }^{1}$, \\ Mohammed Ashif Imtiaz ${ }^{5}$ and Goutam Buddha Das ${ }^{1}$
}

\begin{abstract}
1. Department of Animal Science and Nutrition, Chittagong Veterinary and Animal Sciences University, Khulshi, Chittagong-4202, Bangladesh; 2. Department of Medicine and Surgery, Faculty of Veterinary Medicine, Chittagong Veterinary and Animal Sciences University, Khulshi, Chittagong-4202, Bangladesh;

3. Department of Microbiology, Faculty of Veterinary Medicine, Chittagong Veterinary and Animal Sciences University, Khulshi, Chittagong-4202, Bangladesh; 4. Department of Pathology and Parasitology, Faculty of Veterinary Medicine, Chittagong Veterinary and Animal Sciences University, Khulshi, Chittagong-4202, Bangladesh;

5. Department of Physiology, Biochemistry and Pharmacology; Faculty of Veterinary Medicine, Chittagong Veterinary and Animal Sciences University, Khulshi, Chittagong-4202, Bangladesh.

Corresponding author: Mukti Barua, email: mukti.barua@yahoo.com; Cell: +88-01846335679

MAMP: cvasu.prodhan@rocketmail.com, KI: kamruldvm13@gmail.com: SC: sharminchowdhury@ygmail.com, MH: anikzaman@yahoo.com, MAI: ashif.shawn@gmail.com, GBD: gbmadhu07@yahoo.com
\end{abstract}

Received: 09-04-2014, Revised: 03-05-2014, Accepted: 05-06-2014, Published online: 14-07-2014

doi: 10.14202/vetworld.2014.483-488 How to cite this article: Barua M, Prodhan MAM, Islam K, Chowdhury S, Hasanuzzaman M,Imtiaz MA and Das GB (2014) Sub-clinical mastitis prevalent in dairy cows in Chittagong district of Bangladesh: detection by different screening tests, Veterinary World 7(7): 483-488.

\begin{abstract}
Aim: Mastitis is recognized as one of the most costly health disorder affecting dairy cows. An epidemiological study was carried out at some selected farms in Chittagong district of Bangladesh to determine the prevalence and risk factors of subclinical mastitis (SCM) in dairy cows.
\end{abstract}

\begin{abstract}
Materials and Methods: For conducting the study, some dairy farms of Chittagong were selected from urban and periurban areas by stratified random sampling. A total of 444 quarter samples of 111 (56 from commercial dairy farms and 55 from backyards) lactating dairy cows were considered. Sub-clinical mastitis (SCM) was determined using three different indirect screening tests: California Mastitis Test (CMT), White Slide Test (WST) and Surf Field Mastitis Test (SFMT). Sensitivity and specificity were also determined to measure the accuracy of those tests.
\end{abstract}

Results: The prevalence of SCM by CMT, WST and SFMT were 32.43\% ( $\mathrm{n}=144), 33.56 \%(\mathrm{n}=149)$ and $31.53 \%(\mathrm{n}=140)$, respectively. Distribution of SCM in relation to different variables at quarter level and animal level was also recorded. The prevalence of SCM was significantly $(\mathrm{P}<0.05)$ higher in aged, high yielding cows in addition with history of periparturient diseases, without dry cow therapy both at quarter and animal level. A significantly $(\mathrm{p}<0.01)$ higher prevalence $(48.98 \%)$ of SCM was observed in higher parity number $(>4)$ than others at quarter level. No significant difference $(\mathrm{P}>0.05)$ was found in relation to breed. Using CMT as a gold standard, sensitivity and specificity of WST and SFMT were also calculated at $95 \%$ confidence interval. The sensitivity, specificity, positive likelihood ratio, negative likelihood ratio, positive predictive value, negative predictive value and disease prevalence by WST and SFMT were comparable.

Conclusion: This study recommends that regular screening of sub-clinical mastitis will reduce the prevalence of sub-clinical mastitis. The most effective way to control sub-clinical mastitis is to take preventive measures such as regular cleaning of the floor, keeping the udder clean, milkman's cleanliness, dry cow therapy specially in high yielding dairy cows.

Keywords: CMT, sensitivity, SFMT, specificity, sub-clinical mastitis, WST.

\section{Introduction}

Mastitis is recognized as one of the devastating maladies of milch animals which causes huge production losses to livestock industry. At present, it is one of the most economically important diseases worldwide $[1,2]$. Inflammation of the parenchyma of mammary gland is called mastitis [3]. Major organisms causing infection are Staphylococci spp., Streptococci spp., and gram-negative bacteria [4]. The Clinical Mastitis (CM) is accompanied by physical, chemical, pathological and bacteriological changes both in milk and glandular tissues [5]. In Sub-clinical mastitis (SCM) there are no

Copyright: The authors. This article is an open access article licensed under the terms of the Creative Commons Attribution License (http://creativecommons.org/licenses/by/2.0) which permits unrestricted use, distribution and reproduction in any medium, provided the work is properly cited. visible abnormalities in udder tissues except an elevated Somatic Cell Count (SCC) [6]. Maintaining hygiene with antimicrobial therapy plays a role in mastitis control by reducing the levels of herd infection [7].

Among different tests, California Mastitis Test (CMT) [8], White Slide Test (WST) [9] and Surf Field Mastitis Test (SFMT) [10] are considered as simple, easily applicable, rapid indirect screening tests for determining SCM. Reagents of these tests contain detergents which change the structure and conductivity of cell membrane and nucleus of somatic cells, stimulate proteolytic enzymes, and increase milk viscosity [11]. Sensitivity of a clinical test refers to the ability of the test to correctly identify those patients with the disease and specificity refers ability to correctly identify those patients without the disease [12]. Detection of SCM 
Table-1: Prevalence of SCM in dairy cows detected by three different tests

\begin{tabular}{llccccc}
\hline Variables & Tests used & No. of sample tested & No. (+)ve & \% (+) ve & $\mathbf{9 5 \%} \mathbf{C l}$ & Overall prevalence \\
\hline Tests & CMT & 444 & 144 & $32.43 \%$ & 28.08 to $36.78 \%$ & $32.51 \%$ \\
& WST & & 149 & $33.56 \%$ & 29.17 to $37.95 \%$ & 28.5 to $36.87 \%$ \\
& SFMT & & 140 & $31.53 \%$ & 27.21 to $35.85 \%$ & \\
\hline
\end{tabular}

CI: Confidence interval

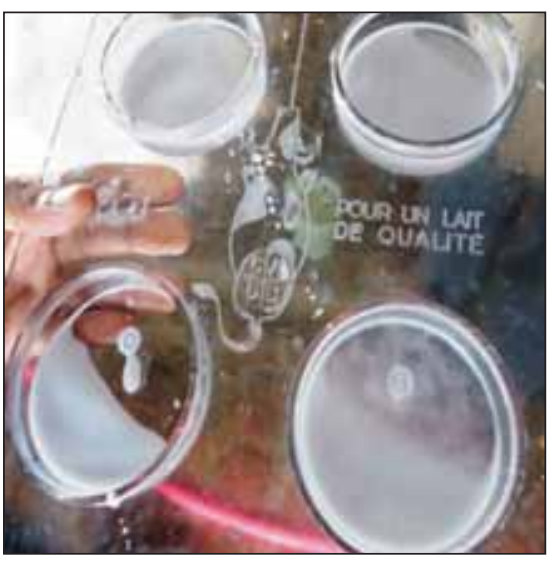

Figure-1(a): Positive california Mastitis Test (visible gel formation within 20 seconds)

and implementation of effective preventive measures will reduce the treatment cost in dairy farms by reducing the clinical occurrence of the disease.

Chittagong is considered as the milk pocket of the south-east part of Bangladesh. There is no Chittagong based study for SCM. Therefore, the present study was conducted to detect the prevalence and associated risk factors of sub-clinical mastitis in lactating cows using three indirect screening tests (i.e. CMT, WST and SFMT), and to evaluate sensitivity and specificity of these tests.

\section{Materials and Methods}

Ethical approval: Approval was taken from ethical committee of Faculty of Veterinary Medicine, Chittagong Veterinary and Animal Sciences University for using animals by describing the protocols of the study. After explanation of the objectives of the study, consent was taken from all participating smallholder dairy farmers. Collection of milk samples was done by following standard operating procedure and questionnaire responses were given on a voluntary basis.

Study area and study period: The study was conducted during the period June to December of 2012 at Chittagong district, the south-east part of Bangladesh. Both commercial and backyard dairy cows from urban and periurban areas were selected by stratified random sampling.

Selection of cases: A total of 444 samples from each quarter of 111 cows (56 commercial dairy and 55 backyards) were tested for mastitis.

Questionnaire preparation and data collection: A questionnaire was designed to comprise mostly closed ended (categorical) questions to ease data processing, minimize variation and improve precision of responses

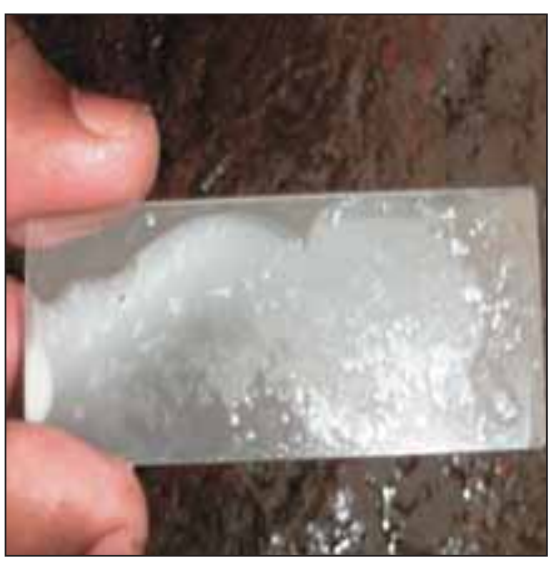

Figure-1 (c): Positive Surf Field Mastitis Test (Background is whey like with clumps of coagulated matter)

[13]. It was prepared to collect both herd and animal level data including herd size, no. of parity, pregnancy stage, age, milk yield, history of periparturient disease, type of stimuli before milking, presence or absence of dry cow therapy, type of breed etc. Information gathered in the questionnaire was entered in the Microsoft Excel worksheet, 2007.

Detection of sub-clinical mastitis: Milk samples were collected at the time of morning milking of cows. All those samples collected from four quarters of every cow were subjected to CMT, WST, SFMT and results were recorded separately.

California mastitis test (CMT): The reagent commercial CMT kit (Leukocytest $\AA$, Synbiotic Corporation, France) used composed of Alkyl Aryl Sulfonate $(3 \%)$, Sodium hydroxide $(1.5 \%)$ and bromocresol purple $(1: 10,000)$ as an indicator. The test was performed and scored according to manufactures instructions (Figure-1a).

White slide test: Using $4 \% \mathrm{NaOH}$ as reagent, WST was performed and scored as per procedure described by Kahir [9] (Figure-1b).

Surf field mastitis test: SFMT was performed with 3\% surf solution (Surf Excel, Unilever, Bangladesh) and scored following the method described by Muhammad et al. [10] (Figure-1c).

Statistical analysis: Data management and analysis were performed using STATA version 12.1 (STATA Corp., College station, Texas). Descriptive analysis was performed by means of frequency (N\%) of positive and negative cow and quarter level test results overall and stratified by different explanatory variables. Chi square test was conducted to test the association between different explanatory variables with the outcome (cow 
Table-2: Distribution of SCM at quarter level in relation to different variables

\begin{tabular}{|c|c|c|c|c|c|}
\hline Variables & Level & No. of observation & Mastitis (+)ve N (\%) & Chi square value & $P$ value \\
\hline Parity & $\begin{array}{l}\text { Parity } 1 \text { (1-3) } \\
\text { Parity } 2 \text { (4-next) }\end{array}$ & $\begin{array}{l}248 \\
196\end{array}$ & $\begin{array}{l}93(37.50 \%) \\
96(48.98 \%)\end{array}$ & 5.90 & 0.02 \\
\hline Pregnancy & $\begin{array}{l}\text { Fresh } \\
\text { Pregnant }\end{array}$ & $\begin{array}{l}228 \\
216\end{array}$ & $\begin{array}{c}67(29.38 \%) \\
122(53.50 \%)\end{array}$ & 32.365 & 0.00 \\
\hline Age & $\begin{array}{l}3-8 \text { years } 260 \\
9-18 \text { years }\end{array}$ & $\begin{array}{c}99(38.07 \%) \\
184\end{array}$ & $\begin{array}{c}7.26 \\
84(45.65 \%)\end{array}$ & 0.01 & \\
\hline Milk yield & $\begin{array}{l}\text { Low }(1-5) 124 \\
\text { Medium }(6-10) \\
\text { High }(>10)\end{array}$ & $\begin{array}{c}47(37.90 \%) \\
140 \\
176\end{array}$ & $\begin{array}{c}11.01 \\
49(35.00 \%) \\
93(52.94 \%)\end{array}$ & 0.00 & \\
\hline \multicolumn{6}{|c|}{ History of periparturient disease } \\
\hline & $\begin{array}{l}\text { Absent } \\
\text { Present }\end{array}$ & $\begin{array}{l}224 \\
220\end{array}$ & $\begin{array}{c}65(29.01 \%) \\
118(53.63 \%)\end{array}$ & 32.901 & 0.00 \\
\hline \multicolumn{6}{|c|}{ Stimuli of cow before milking } \\
\hline & $\begin{array}{l}\text { Clean water } \\
\text { Mustard oil } \\
\text { Calf }\end{array}$ & $\begin{array}{l}116 \\
144 \\
184\end{array}$ & $\begin{array}{l}43(37.07 \%) \\
51(35.42 \%) \\
95(51.63 \%)\end{array}$ & 10.63 & 0.01 \\
\hline Dry cow therapy & $\begin{array}{l}\text { Present } \\
\text { Absent }\end{array}$ & $\begin{array}{c}368 \\
76\end{array}$ & $\begin{array}{l}147(39.95 \%) \\
42(55.26 \%)\end{array}$ & 6.0453 & 0.01 \\
\hline Breed & $\begin{array}{l}\text { HF } \times \text { Local } \\
\text { HF } \times \text { SL } \\
\text { SL } \times \text { Local }\end{array}$ & $\begin{array}{l}112 \\
188 \\
144\end{array}$ & $\begin{array}{l}55(49.11 \%) \\
83(44.15 \%) \\
51(35.42 \%)\end{array}$ & 5.1635 & 0.08 \\
\hline
\end{tabular}

Table-3: Distribution of SCM at animal level in relation to different variables

\begin{tabular}{|c|c|c|c|c|c|}
\hline Variables & Level & No. of observation & Mastitis (+)ve N (\%) & Chi square value & $P$ value \\
\hline Parity & $\begin{array}{l}\text { Parity } 1(1-3) \\
\text { Parity } 2 \text { (4-next) }\end{array}$ & $\begin{array}{l}62 \\
49\end{array}$ & $\begin{array}{l}26(41.94 \%) \\
26(53.06 \%)\end{array}$ & 1.305 & 0.24 \\
\hline Pregnancy & $\begin{array}{l}\text { Fresh } \\
\text { Pregnant }\end{array}$ & $\begin{array}{l}56 \\
55\end{array}$ & $\begin{array}{l}18(32.14 \%) \\
34(61.82 \%)\end{array}$ & 9.8132 & 0.01 \\
\hline Age & $\begin{array}{l}3-8 \text { years } \\
9-18 \text { years }\end{array}$ & $\begin{array}{l}65 \\
46\end{array}$ & $\begin{array}{l}24(36.92 \%) \\
29(63.04 \%)\end{array}$ & 10.712 & 0.00 \\
\hline Milk yield & $\begin{array}{l}\operatorname{Low}(1-5) \\
\text { Medium }(6-10) \\
\text { High }(>10)\end{array}$ & $\begin{array}{l}31 \\
35 \\
44\end{array}$ & $\begin{array}{c}9(17.31 \%) \\
15(42.85 \%) \\
29(65.91 \%)\end{array}$ & 11.01 & 0.02 \\
\hline History of peripar & rient disease & & & & \\
\hline & $\begin{array}{l}\text { Absent } \\
\text { Present }\end{array}$ & $\begin{array}{l}56 \\
55\end{array}$ & $\begin{array}{l}19(33.92 \%) \\
34(61.82 \%)\end{array}$ & 9.3369 & 0.00 \\
\hline Stimuli of cow be & re milking & & & & \\
\hline & $\begin{array}{l}\text { Clean water } \\
\text { Mustard oil } \\
\text { Calf }\end{array}$ & $\begin{array}{l}29 \\
36 \\
46\end{array}$ & $\begin{array}{l}12(41.38 \%) \\
15(41.67 \%) \\
25(54.35 \%)\end{array}$ & 1.7755 & 0.41 \\
\hline Dry cow therapy & $\begin{array}{l}\text { Present } \\
\text { Absent }\end{array}$ & $\begin{array}{l}19 \\
92\end{array}$ & $\begin{array}{l}11(57.89 \%) \\
41(44.57 \%)\end{array}$ & 1.1237 & 0.28 \\
\hline Breed & $\begin{array}{l}\text { HF } \times \text { Local } \\
\text { HF } \times \text { SL } \\
\text { SL } \times \text { Local }\end{array}$ & $\begin{array}{l}28 \\
47 \\
36\end{array}$ & $\begin{array}{c}14(50 \%) \\
23(48.94 \%) \\
15(41.57 \%)\end{array}$ & 0.5822 & 0.75 \\
\hline
\end{tabular}

positive/negative and quarter positive/negative). A significance level was selected as 5\%.

Accuracy of tests: Sensitivity and specificity of CMT was highest than SCC (Somatic cell count) and WST, SFMT, respectively $[14,15]$. Using CMT as a gold standard, no. of positive and negative animals in WST and SFMT was recorded and sensitivity, specificity, likelihood ratio, predictive value and disease prevalence of WST and SFMT were also calculated.

\section{Results}

A total of 444 samples from 111 cows were tested for the presence or absence of SCM. During the study, a questionnaire was prepared and information about different variables (i.e. parity, age, pregnancy status, milk yield, history of periparturient diseases etc.) from individual animal was recorded.

The prevalence of CMT, WST and SFMT which was higher in WST $(33.56 \%)$ compared to CMT (33.56\%) and SFMT (31.53\%) (Table-1).

The association in prevalence of SCM in relation to difference in age, parity, pregnancy status, amount of milk production, methods of stimuli before milking, history of periparturient diseases, presence or absence of dry cow therapy was significant $(\mathrm{P}<0.05)$ (Table-2). Parity 4 to rest showed greater prevalence $(48.98 \%)$ of mastitis than parity 1 to $3(37.50 \%)$. Prevalence $(53.50 \%)$ was higher in pregnant cows than fresh cows (29.38\%). Advancing age (9-18 years) showed higher prevalence $(45.65 \%)$ than lower age (3-8 years) which was (38.07\%). High milk producing cows showed greater prevalence $(52.94 \%)$ than medium $(35.00 \%)$ and low producing cows (37.90\%). Increased prevalence $(53.63 \%)$ was seen in cows with history of periparturient diseases. Cows which were given stimuli by calves prior to milking showed greater prevalence (51.63\%) than in cows which were stimulated by other methods. Prevalence $(55.26 \%)$ of SCM was more in cows without dry cow therapy than cows with dry cow therapy (39.95\%). No significant association was seen in prevalence of mastitis in different breeds $(\mathrm{P}=0.08)$.

There was no significant association was found $(\mathrm{P}>0.05)$ in prevalence of cows with difference in 
Table-4: Sensitivity, specificity, predictive value, likelihood ratio and disease prevalence of WST and SFMT using CMT as a gold standard

\begin{tabular}{lll}
\hline Parameters & WST & SFMT \\
\hline Sensitivity & $75.69 \%[95 \% \mathrm{Cl}: 67.85$ to $82.45 \%]$ & $78.47 \%[95 \% \mathrm{Cl}: 70.86$ to $84.88 \%]$ \\
Specificity & $86.67 \%[95 \% \mathrm{Cl}: 67.85$ to $82.45 \%]$ & $91.00 \%[95 \% \mathrm{Cl}: 87.18$ to $93.98 \%]$ \\
Positive likelihood ratio & $5.68[95 \% \mathrm{Cl}: 4.19$ to 7.69$]$ & $8.72[95 \% \mathrm{Cl}: 6.02$ to 12.62$]$ \\
Negative likelihood ratio & $0.28[95 \% \mathrm{Cl}: 0.21$ to 0.38$]$ & $0.24[95 \% \mathrm{Cl}: 0.17$ to 0.32$]$ \\
Positive predictive value & $73.15 \%[95 \% \mathrm{Cl}: 65.29$ to $80.08 \%]$ & $80.71 \%[95 \% \mathrm{Cl}: 73.19$ to $86.89 \%]$ \\
Negative predictive value & $88.14 \%[95 \% \mathrm{Cl}: 83.89$ to $91.59 \%]$ & $89.80 \%[95 \% \mathrm{Cl}: 85.84$ to $92.96 \%]$ \\
Disease prevalence & $32.43 \%[95 \% \mathrm{Cl}: 28.10$ to $37.01 \%]$ & $32.43 \%[95 \% \mathrm{Cl}: 28.10$ to $37.01 \%]$ \\
\hline
\end{tabular}

parity numbers, methods of stimuli before milking, presence or absence of dry cow therapy, type of breeds. The association in prevalence of animals with difference in pregnancy status, age, quantity of milk production, history of periparturient diseases was significant $(\mathrm{P}<0.05)$ (Table-3). Pregnant animals showed greater prevalence $(61.82 \%)$ of SCM than fresh animals. 9 to 8 years old aged animals showed higher prevalence $(63.04 \%)$ than lower aged animals $(36.92 \%)$. Higher prevalence $(65.91 \%)$ was also seen in high milk producing cows than medium $(42.85 \%)$ and low producing cows $(17.31 \%)$. Cows with history of periparturient disease showed greater prevalence $(61.82 \%)$ of SCM than cows without periparturient disease (33.92\%).

The sensitivity, specificity of WST and SFMT were $75.69,86.67 \%$ and $78.47,91 \%$, respectively. Positive likelihood ratio, negative likelihood ratio, positive predictive value, negative predictive value and disease prevalence of WST and SFMT were also determined with $95 \%$ confidence interval (Table- 4 ).

\section{Discussion}

Overall prevalence of CMT, WST and SFMT was $32.51 \%$ (Table-1). The prevalence was almost nearer to the findings of [14] who reported $36.46 \%$ prevalence of SCM in lactating dairy cows. The prevalence recorded by Kader et al. [15] was $46.6 \%$, which was slightly higher than my findings. Higher prevalence was reported by [16] and lower prevalence was reported by [17]. Difference in prevalence of SCM might be due to geographical locations, difference of breed, management systems etc.

The prevalence of SCM by WST was 33.56\% $(\mathrm{n}=149)$. SCM showed better performance in detecting SCM compared to CMT (32.43\%) and SFMT $(31.53 \%)$ (Table1). This result is in agreement with the findings of Prodhan et al. [18]. On the contrary, higher prevalence of SCM was recorded in CMT (37.58\%) than WST and SFMT [14].

Several studies were in agreement with the present findings of increased mastitis with the advancing parity [18]. The prevalence of SCM at quarter level was significantly higher $(\mathrm{P}<0.05)$ in parity 4 to above 4 than parity 1 to 3 (Table-2). This association was significant $(\mathrm{P}>0.05)$ (Table-3) at animal level also. It has been shown that high-yielding dairy cows are more prone to mastitis as the glandular tissues are more susceptible to infection [19]. Interestingly, high parity cows are more productive, and it is likely that cows with advancing parity are prone to mastitis.
Out of 216 samples which were taken from quarters of pregnant animals, $53.50 \%(\mathrm{n}=122)$ were positive for SCM, was significantly higher $(\mathrm{P}<0.05)$ compared to samples taken from fresh animal (29.38\%). At animal level there was also a statistically significant difference $(\mathrm{P}<0.05)($ Table-2). It is reported that the prevalence of mastitis is often high in last stage of pregnancy followed by a marked decline after parturition [19].

The distribution of SCM at quarter level was $45.65 \%(n=84)$ in the age group belonging to 9 to 18 years, was significantly $(\mathrm{P}<0.05)$ higher than the prevalence $(38.07 \%)$ found in 3 to 8 years old cows (Table-2). At animal level, the difference was also statistically significant $(\mathrm{P}<0.05) \quad($ Table-3). Similar observation was also reported by $[14,17]$.

The prevalence of SCM at quarter level was significantly $(\mathrm{P}<0.05)$ higher in high $(52.94 \%)$ yielding cows than low $(37.50 \%)$ to medium $(35 \%)$ yielders (Table-2). This association was also statistically significant in animal level $(\mathrm{P}<0.05)$ (Table- 3$)$. The previous findings on effects of milk production in the prevalence of SCM were in agreement with Islam et al. [14] who reported greater prevalence of mastitis in high yielding cows.

Quarter wise prevalence of SCM in cows without a history of periparturient disease was $29.01 \%(n=65)$; in contrast, $53.63 \%(\mathrm{n}=118)$ prevalence was recorded in cows with a history of periparturient disease (Table$2)$. This difference differed significantly $(\mathrm{P}<0.05)$. At animal level, this difference was also significantly higher $(\mathrm{P}<0.05)$ (Table-3). The lower immunity level of periparturient cows makes the cow more prone to infection in the udder. Higher prevalence of mastitis in cows with a history of periparturient disease was also recorded by Rahman et al. [17].

The prevalence of SCM at quarter level was higher $(51.63 \%)$ in cows given stimuli by the calves, compared to other methods of stimuli (Table-3). This difference was significant $(\mathrm{P}<0.05)$ statistically (Table$3)$. At animal level, the prevalence $(54.35 \%)$ of SCM was also higher. This difference may be due to laceration of teat sphincter by biting of calves. It is reported that mastitis may result following the introduction of microorganisms through the teat sphincter [20] which can occur after laceration and injury to the udder.

At quarter level, 39.95\% ( $\mathrm{n}=147)$ prevalence of SCM was found in dairy cows where dry cow therapy was used which was less than the prevalence $(55.26 \%)$ of SCM in dairy cows without dry cow therapy. Those 
values differed significantly $(\mathrm{P}<0.05)$ (Table-2). No significant difference $(\mathrm{P}>0.05)$ was found in animal level (Table-3). It is reported that, dry cow therapy is essential to achieve an efficient control program of mastitis [21]. Differences in prevalence of different breeds were not statistically significant $(\mathrm{P}>0.05)$ both at quarter (Table-2) and animal level (Table-3). These results are in agreement with the findings of [14,17].

The sensitivity, specificity, positive likelihood ratio, negative likelihood ratio, positive predictive value, negative predictive value and disease prevalence of WST and SFMT were $75.69 \%, 86.67 \%, 5.68,0.28$, $73.15 \%, 88.14 \%, 32.43 \%$ (Table 4 ) and $78.47 \%, 91 \%$, $8.72,0.24,80.71 \%, 88.80 \%$ and $32.43 \%$, respectively (Table-4). In a previous study, sensitivity and specificity of WST and SFMT were recorded as 75.73 and $54.37 \%$, respectively [22].

\section{Conclusion}

Mastitis is a common problem of dairy industries. Reduction in milk production and an irreparable damage to the udder associated with the disease are the common causes of culling of dairy cows. Milk from infected animals is not suitable for drinking and for making different milk products. So it has a major economic importance in dairy cattle. The prevalence of sub-clinical mastitis increases in cows with a history of periparturient disease, cows without dry cow therapy, high milk producing cows and in cows with the advancing age and parity. CMT, WST and SFMT are easily applicable and cost effective tests for regular screening of sub-clinical mastitis. For controlling mastitis, hygiene should be maintained at every aspect of dairy farms as there is no vaccine for mastitis. Care and management should be improved. Infected milk should be properly disposed. $5 \%$ phenol may be added to the infected milk at the time of disposal. All the equipments and containers should be cleaned and washed properly. At the same time farmers should be aware about the importance of the disease.

\section{Authors' contributions}

$\mathrm{MB}$ and SC implemented the study design. MB, KI and MAI performed all the tests. MB and MAMP drafted, $\mathrm{MH}$ and GBD revised the manuscript. All authors read and approved the final version of manuscript.

\section{Acknowledgements}

The authors are grateful to The Department of Medicine and Surgery, Chittagong Veterinary and Animal Sciences University for support and providing fund for the present research. The authors also would like to thank the staffs and farmers of experimented dairy farms of Chittagong, Bangladesh.

\section{Competing interests}

The authors declare that they have no competing interests.

\section{References}

1. Hashemi, M., Kafi, M. and Safdarian, M. (2011) The prevalence of clinical and subclinical mastitis in dairy cows in the central region of Fars province, south of Iran. Iran J. VetRes., 12:3.

2. Chishty, M.A., Arshad, M., Avais, M. and Ijaz, M. (2007) Cross-sectional epidemiological studies on mastitis in cattle and buffaloes of tehsil Gojra Pakistan, Buff. Bull., 26: 50-55.

3. Souto, L.I., Minagawa, C.Y., Telles, E.O., Garbuglio, M.A., Amaku, M., Melville, P.A., Dias, R.A., Sakata, S.T. and Benites, N.R. (2010) Correlation between mastitis occurrence and the count of microorganisms in bulk raw milk of bovine dairy herds in four selective culture media. $J$. Dairy Res., 77: 63-70.

4. Mubarack, H.M., Doss, A., Vijayasanthi, M. and Venkataswamy, R. (2012) Antimicrobial drug susceptibility of Staphylococcus aureus from subclinical bovine mastitis in Coimbatore,Tamilnadu, South India. Vet. World, 5(6): 352-355.

5. Samad, M.A. (2008) Animal Husbanry and Veterinary Science, LEP pub no.11, Bangladesh Agricultural University campus, Mymensingh, 2: 1184-1189.

6. MacDougall, S.P., Murdough, W., Pankey, C., Delaney, Barlow, J. and Scruton, D. (2001) Relationships among somatic cell count, California mastitis test, impedance and bacteriological status of milk in goats and sheep in early lactation. Small Rumin. Res., 40: 245-254.

7. Unakal, C.G. and Kaliwal, B.B. (2010) Prevalence and antibiotic susceptibility of Staphylococcus aureus from bovine mastitis. Vet. World, 3(2):65-67.

8. Contreras, A., Correlas, J.C., Sierra, D. and Marco, J. (1995) Prevalence and aetioloogy of nonclinical intramammary infection in murciano-granadian goats. Small Rumin. Res., 17: 71-78.

9. Kahir, M.A. (2006) A cross sectional epidemiological study on subclinical mastitis of dairy cows in Sylhet. MS Thesis., Department of Medicine, Bangladesh Agricultural University, Mymensingh, Bangladesh.

10. Muhammad, G., Athar, M., Shakoor, A., Khan, M. Z., Fazalur-Rehman and Ahmad M. T. (1995) Surf Field Mastitis Test: An inexpensive new tool for evaluations of wholesomeness of fresh milk. Pak. J. Food Sci., 5:91-93.

11. Middleton, J.R., Hardin, D., Steevens, B., Randle, R. and Tyler, J. (2004) Use of somatic cell counts and California mastitis test results from individual quarter milk samples to detect subclinical intramammary infection in dairy cattle from a herd with a high bulk tank somatic cell count. J. Am. Vet. Med.Assoc., 224: 419-423.

12. Lalkhen, A. G., McCluskey, A. (2013). Clinical tests: sensitivity and specificity. Oxford J. Med., 8:221-223.

13. Thrusfield, M. (2005) Criteria for Success of Questionnaire. In: Veterinary Epidemiology, $3^{\text {rd }}$ ed., Blackwell Science, Oxford, UK, 189-213.

14. Islam, M.A., Rahman, A.K.M.A., Rony, S.A. and Islam, M.S. (2010) Prevalence and risk factors of mastitis in lactating dairy cows at Baghabari milk shed area of Sirajganj. Bangladesh.J. Vet. Med., 8(2): 157-162.

15. Kader, M.A., Samad, M.A. and Saha, S. (2003) Influence of host level factors on prevalence and economics of subclinical mastitis in dairy cows in Bangladesh. Indian $J$. Dairy Sci., 56: 235-240.

16. Motice, A., Ramudit, S. and Mohabir, R. (1985) Subclinical mastitis in dairy cattle in Guyana. Trop. Anim. Health Prod., 17: 245-246.

17. Rahman, M.A., Bhuiyan, M.M.U., Kamal, M.M. and Shamsuddin,M. (2009) Prevalence and risk factors of mastitis in dairy cows. Bangladesh Vet., 26(2):54-60.

18. Prodhan, M.A.M., Kamal, A.H.M. and Mahbub-E-Elahi, A.T.M. (1996) Prevalence of sub-clinical mastitis in cows of Baghabari Milkshed area. Bangladesh Vet. J., 30: 59-61.

19. Radostits, O.M., Gay, C.C., Blood, D.C. and Hinchcliff, K.W. (2000) Mastitis. In: Veterinary Medicine, $9^{\text {th }}$ ed., Saunders, Edinburg, p603-622.

20. Dulin, A.M, Paape, M.J. and Nickerson, S.C. (1988) Comparison of phagocytosis and chemiluminescence by 
blood and mammary gland neutrophils from multiparous and nulliparous cows. Am. J. Vet. Res., 9: 172-177.

21. Hashemi, M., Kafi, M. and Safdarian, M. (2011) The prevalence of clinical and subclinical mastitis in dairy cows in the central region of Fars province, south of Iran. Iran J.
Vet. Res., 12: 3 .

22. Muhammad, G., Naureen, A., Sadiq, M., and Fazal-urRehman (2010) Evaluation of a 3\% surf solution (surf field mastitis test) for the diagnosis of subclinical bovine and bubalinemastitis. Trop. Anim. Health Prod., 42(3): 457-64.

\section{$* * * * * * * *$}

